\title{
Paideusis
}

\section{Experiences in Philosophy of Education: A Self-Portrait}

\section{Clive Beck}

Volume 19, Number 2, 2010

URI: https://id.erudit.org/iderudit/1071917ar

DOI: https://doi.org/10.7202/1071917ar

See table of contents

Publisher(s)

Canadian Philosophy of Education Society

ISSN

0838-4517 (print)

1916-0348 (digital)

Explore this journal

Cite this document

Beck, C. (2010). Experiences in Philosophy of Education: A Self-Portrait.

Paideusis, 19(2), 10-15. https://doi.org/10.7202/1071917ar

This document is protected by copyright law. Use of the services of Erudit (including reproduction) is subject to its terms and conditions, which can be viewed online.

https://apropos.erudit.org/en/users/policy-on-use/
This article is disseminated and preserved by Érudit.

Érudit is a non-profit inter-university consortium of the Université de Montréal, Université Laval, and the Université du Québec à Montréal. Its mission is to promote and disseminate research.

https://www.erudit.org/en/ 
Paideusis, Volume 19 (2010), No. 2., pp. 10-15

\title{
Experiences in Philosophy of Education: A Self- Portrait
}

\author{
CLIVE BECK \\ Ontario Institute for Studies in Education, University of Toronto
}

\section{What Led Me to Philosophy and Philosophy of Education}

I grew up on a somewhat remote sheep farm in Western Australia and did my early and final years of schooling by distance education. My mother was a school teacher so she could help supervise me, especially in grades 1 and 2. From grades 3 to 10, I went by bus to local public schools. The last two "leaving" years were spent in splendid isolation doing correspondence courses.

My two older brothers led the flight from farm to university and, when I finished school, I went off to the University of Western Australia (UWA). My four-year B.Ed. degree included teacher certification. However, I also opted for some fairly academic studies: honours in philosophy of education, a major in history, and courses in philosophy and Greek.

After graduating, I worked part-time and enrolled in another bachelor's degree at the University of Sydney, doing honours in general philosophy and more courses in classical Greek. I then became a lecturer in philosophy of education at the University of New England (UNE), just north west of Sydney. At the same time, I did a Ph.D. in philosophy at UNE with a focus on philosophy of education. In 1967, I got a position in philosophy of education at the Ontario Institute for Studies in Education (OISE) at the University of Toronto on the recommendation of Israel Scheffler, one of my doctoral examiners.

Given my roots, why all this early interest in philosophy and philosophy of education? Cynics might explain it in terms of exposure to vast horizons and myriad sheep. Others might refer to my strongly religious upbringing (long since left behind). But the farm experience was, of course, quite practical, and our religion was rather unreflective, concerned more with getting into the next world than understanding the present one. I think it was more a matter of personality. It was in my nature to enjoy theorizing about life, society, and reality in general. Also, being something of an optimist, I had accepted (naively, I think now) the general Western notion that "the truth will make you free", that getting to the bottom of things leads rather quickly to personal and societal transformation. I saw philosophy not only as enjoyable but as potentially very useful. Finally, philosophy of education at that time offered employment, and with wool prices plummeting, it seemed like a congenial alternative.

\section{Early Experiences in Philosophy and Philosophy of Education}

At UWA, my sole instructor and honours supervisor in philosophy of education was T.A. (Bert) Priest. He broadly advocated the British analytic approach to philosophy and introduced us to thinkers such as A.J. Ayer, D.J O'Connor, and Israel Scheffler. However, he also recommended that we read Dewey's

(C) Copyright 2010. The author, Clive Beck, assigns to Paideusis the right of first publication and educational and non-profit institutions a non-exclusive license to use this document for personal use and in courses of instruction provided that the article is used in full and this copyright statement is reproduced. Any other usage is probibited without the express permission of the author. 
Democracy and Education, and Brubacher's Modern Philosophies of Education, works that dealt with substantive issues. He was supportive of my research paper on "The Concept of Nature in Rousseau's Emile" which, while not defending a particular position, did explore substantive views of human nature.

Many faculty in philosophy departments in Australia at this time were going beyond the analytic approach — or had not embraced it in the first place — and this reinforced my natural inclination toward substantive theorizing. When I moved to the University of Sydney, I studied in depth the current critiques of analytic philosophy. My main ethics professor, who supervised my thesis on "The Justification of Moral Judgments", was a committed Aristotelian. He helped me reject the then common view that morality is based on arbitrary emotional response and develop instead the position that it is (or should be) concerned with promoting human well-being or "the good life."

At UNE, my doctoral studies were supervised first by Nirmal Bhattacharyya of the education department (who later went to the University of Alberta) and then Richard Routley of the philosophy department. They were both open to the mixture of analysis and substantive theorizing I was then using. My thesis, titled "Value Statements in Educational Discourse", presented a general theory of ethics with an "education tail." However, because I saw ethics not as an "autonomous" discipline in the Kantian sense but as based in everyday human affairs, the thesis dealt with many aspects of human nature, life, and society. It provided the beginnings of my later general theorizing about the goals and processes of education.

\section{Swimming in Mainstream Philosophy of Education, 1967-1997}

At OISE/University of Toronto, we had for thirty years perhaps that largest contingent of philosophers of education in the world. We taught only at the graduate level, not being involved in any aspect of preservice teacher education until the mid-90s. As a matter of policy, all of us had a background in some "pure" philosophical area-for example, social philosophy, philosophy of mind, ethics, philosophy of science-and applied this specialist knowledge to issues in education. The application was at a fairly theoretical level and often in just one aspect of education. General knowledge of the practice of schooling was not seen as essential. The idea was that philosophers of education develop broad educational insights in a given area and these are then integrated and implemented by others at the practical level. This was in keeping with Scheffler's dictum that philosophy of education is concerned with the "roots" rather than the "fruits" of educational inquiry.

This abstract and fragmented approach to philosophy of education was widespread in the English-speaking world at the time. A common narrative of our field was as follows. In the 19th and early $20^{\text {th }}$ centuries, educational philosophers saw philosophy as "the queen of the sciences." Accordingly, they developed grand theories (pragmatist, idealist, realist, rationalist, and so on) that dealt with a large array of theoretical and applied aspects of education. From the 1930s to the 1960s, analytic philosophers maintained that such an approach was neither logically sound nor practically feasible; instead, they advocated an "under-labourer" approach that avoided substantive theorizing and focused on clarifying and criticizing educational concepts and theories developed by others. By the 1970s and 1980s, however, there was broad recognition that the analytic alternative was itself illogical, since in order to clarify and criticize, one has to make substantive assumptions; moreover, there was a reluctance to hand over educational theorizing entirely to others. A compromise was struck, one that did not involve a return to grand theorizing: philosophers of education would often get into substantive matters, but would work largely at the theoretical level and in specialized areas. This was thought to be do-able. As Jonas Soltis said in 1981 in introducing his edited volume Philosophy and Education (Part I of the 80th NSSE Yearbook), "we believe that a structure based on sub-areas of philosophy provides a better match of expectation and philosophical delivery" (8). 
Returning to my personal case, I was naturally influenced by the conception of philosophy of education developing around me. My publications and courses were relatively theoretical and I tended to specialize in my background area of ethics (or values as I usually called it). My courses at OISE included "Values and Schooling", "Values Education", and "Value Inquiry and the Study of Education". Although I spent some time in schools and created curriculum materials, this was mainly in connection with my work in values education.

Increasingly, however, I saw the limitations of this abstract, compartmentalized approach to educational philosophy. In 1974, I wrote Educational Philosophy and Theory, in which I argued that educational inquiry (whether we call it philosophy, theory, or something else), needs to be broad and integrated and draw on a variety of sources. While philosophers of education have distinctive knowledge and skills, the difference between us and other educational inquirers is a matter of degree. If we want to make a significant contribution to education, we must become more comprehensive and also get into matters of practice. The book itself contained some relatively practical chapters-on teaching, learning, and curriculum - that relied on many sources other than ethical theory. In my teaching, too, I was beginning to offer more wide-ranging and practical courses such as "The Logic of the Curriculum" and "The Theory and Practice of Schooling". Over the years, this interest in practice continued to develop, leading for example to my Better Schools (1990) which had chapters on school structure, the role of the teacher, and classroom goals and strategies.

At its 1990 annual meeting, the American Philosophy of Education Society celebrated its $50^{\text {th }}$ anniversary. To mark the occasion a plenary session on the history and role of philosophy of education was organized and I was asked to contribute. ${ }^{1}$ In my paper (Beck, 1991), I once again voiced my concerns about the fragmented nature of our field and our lack of engagement with practice. I argued that schooling is an enormously complex field and making a useful contribution to it requires working on several fronts at once. Accordingly, if philosophers of education are to help with educational practice-which is surely our aim and reason for being-we must abandon our high degree of specialization. Further, as well as crossing boundaries within philosophy of education, we must have constant dialogue with school practitioners and empirically-based educational theorists.

Though respected in the American Philosophy of Education Society (PES) (I was asked to contribute in various ways and became President in 1992), I think I was viewed as something of a maverick. Maxine Greene in her response to my 1990 paper spoke positively of my "good sense" and "comic vision" (in the Greek sense), which she described as "large", "tolerant", and "unperturbed"; however, she urged me toward more "passion and commitment". I have great affection and respect for Maxine Greene and have always valued her feedback. However, I feel that she and others missed my point. My concern for practice (that "good sense") arose from a strong desire to improve the experience of students in schools. My point was that unless we became much more comprehensive and applied in our educational theorizing, we would continue to be little more than dabblers in the real work of educational inquiry and reform. A dramatic change was necessary if we were to help build schools and classrooms that had a major positive impact on the intellectual, social, and personal lives of students. What could be more passionate and committed than that?

Since the late 1980s, philosophy of education has focused less on subfields of philosophy and more on overarching cultural, political, and epistemological issues. Common areas of inquiry have been feminism, racism, multiculturalism, postmodernism, poststructuralism, and postcolonialism. I accept, of course, that such topics are of great importance. They connect both to my interest in values and my concerns about improving the classroom experience of children. My 1993 American PES presidential address (1993a) explored the implications of postmodernist and poststructuralist thought for educational theory and practice; and one of my main ongoing research areas is how to make schooling more inclusive with respect to gender, race, ethnicity, class, and so on. However, I continue to believe that philosophy of education must become more comprehensive and practical in its approach. No

1 The session papers were published the following year in a theme issue of Educational Theory. 
matter how passionately we research and write about the biases and injustices built into contemporary society, culture, and intellectual life, we will have little impact unless we deal with these issues in the context of everyday schooling. Teachers today face enormous demands and challenges. We must help them develop a feasible approach to program planning and classroom life, one that includes equity and critical inquiry as integral components. It is futile simply to make demands on them in particular areas without reference to their total situation.

\section{Ranging from Theory to Practice, 1997-2010}

Over its initial three decades, OISE was an autonomous institution, receiving its research and graduate studies funding directly from the government. However, it was affiliated with the University of Toronto for degree granting purposes and its students earned University of Toronto degrees. In 1996, it gave up its autonomy and was merged with the university's long-standing preservice institution (Faculty of Education, University of Toronto). The new entity became the university's faculty of education, although for historical reasons, it is still called OISE.

This change meant that OISE faculty could now teach readily in both the graduate and preservice programs, and given my applied interests I took advantage of this situation. I had actually begun in preservice in a small way in 1995, but by 1997, about half my teaching was in teacher education, and to this day, I teach two sections of a social foundations course (School \& Society) and do practice teaching supervision. In addition, most of my research and writing since 1997 has been on teaching and teacher education and I regularly attend the American Educational Research Association (AERA) meetings. With these commitments, I do not always have time to go to Canadian and American PES conferences, although I still see myself as a philosopher of education.

For several years prior to the OISE-U of T merger, I had a cross-appointment to OISE's Department of Curriculum, Teaching and Learning (CTL) and taught CTL courses such as "Values and Teaching" and "The Role of the Teacher". In 1998, I left the Philosophy of Education program and transferred fully to CTL, being housed in CTL's Centre for Teacher Development (CTD) and teaching in the CTL graduate program.

An ironic side-note here is that in order to join CTD, I had to get the permission of Mick Connelly, co-founder and for many years head of CTD. When I went to see Mick, he was very cordial and welcoming. However, he reminded me that in the early 1970s, when he first joined CTL, he came to ask me, then Chair of the History and Philosophy Department, whether he could be cross-appointed to History and Philosophy given his background and interest in philosophy of education. I had turned him down on the ground that our policy was to only have faculty with pure philosophy training teaching in the program! I apologized profusely to Mick, saying that I thought we had got it wrong.

Why did I make the shift from Philosophy of Education to CTL? One reason was practical and had to do with doctoral supervision. As my interests became more applied, many doctoral applicants with both a philosophy and schooling background wanted to enter the program and do their thesis research with me. However, they were often unable to find enough other courses in the program that focused sufficiently on schooling. Further, when it came to forming a thesis committee, they had difficulty finding philosophy faculty with sufficient applied interest to serve as committee members. Increasingly, then, I faced a very large supervision load without a lot of support within the program.

Another reason for moving to CTL was that, with growing practical interests (due partly to my involvement in preservice), I wanted to be free to have such an emphasis in my research and teaching. Regarding research, I had begun to study teacher education-the campus courses, the practicum, the experiences of recent graduates - and formulate concrete approaches to teaching and teacher education (e.g., Beck and Kosnik, 2002a, 2002b, 2006; Kosnik and Beck, 2000, 2009). With respect to teaching, I wanted to legitimize the strongly practical component of my graduate courses and also teach more courses in which nearly all the students were (or had been) teachers: I knew from experience that 
having such classes not only made my teaching more relevant, but also helped me refine my ideas about teaching and teacher education.

How do I justify being someone with a background in philosophy of education who nevertheless does extensive research and teaching on the practice of schooling and teacher education? As I said in my 1990 PES paper, schooling is an extremely complex activity requiring insights ranging from the highly theoretical to the very practical. In order to teach well, we must know what our goals are but also have detailed strategies for achieving these goals. And in order to belp teachers teach well—in preservice and graduate courses-we need to run the whole gamut from general theory to everyday practice. Good practice requires theory and good theory requires knowledge of practice (Carr, 1995). There can perhaps be a difference of degree between people who are more theoretically oriented and those who are more practically oriented, but a sharp division of labour has to be rejected. The same applies to subfields within education. A difference of degree may exist between specialists in, say, assessment and classroom management, but each of these specialists must know a great deal about the other field (and many more besides) if they are to develop sound principles and strategies.

But how is this possible? How can we work on all these fronts at once: both theory and practice and a great many subfields of education? The answer is that it is certainly difficult but we have no alternative, because all aspects of education are interconnected. For example, forms of assessment are needed in the classroom that enable teachers to develop an engaging program, attend to other aspects of the teaching situation, get to know their students well, and in general maintain a good relationship with their students. In education, as soon as one key area is left out of the equation we are in danger of making serious mistakes in both theory and practice. Of course, there are dangers also of spreading ourselves too thin. However, I believe that the dangers of a sharp separation between fields far outweigh the dangers of a comprehensive, overlapping approach to educational inquiry.

For me, moving to a more balanced theory-practice mix has not been easy, despite my relatively applied interests over the years. Teaching in the pre-service program has been especially challenging. I teach in a post-baccalaureate B.Ed. program in which the students have just nine months to prepare for full-responsibility teaching. Understandably, they are anxious to learn "how to survive" in the classroom and they wonder about the value of theory and, in particular, the ability of a philosopher to help them acquire an effective approach to teaching. I am happy to report, however, that after fifteen years (and it has taken that long) most students see my "School \& Society" course as a very valuable part of the mix. Reaching this point has been due to many factors: getting to know more about schooling through practicum supervision and school-based research; reading in relevant areas of practice; learning from teachers in my graduate classes; and modifying my preservice course so it is less ideological and more focused on developing an approach to teaching with both practical and theoretical components.

As I said, I still think of myself as a philosopher of education; however, I now see less significance in labels of this kind. All educational inquirers, including university faculty and classroom teachers, are theorists (Carr, 1995). We have to be if we are to figure out the goals and principles of schooling and how the various pieces fit together. Different inquirers have somewhat distinctive insights to offer, depending on our background and talents; but if we are to make a significant contribution, there has to be a great deal of overlap in our knowledge and in the matters we explore.

\section{References}

Ayer, A.J. Language, Truth, and Logic. London: Gollancz, 1958.

Beck, C. Educational Philosophy and Theory. Boston: Little, Brown, 1974.

Beck, C. Better Schools: A V alues Perspective. London: Falmer Press, 1990. 
Beck, C. "North American, British, and Australian philosophy of education from 1941 to 1991: Links, Trends, Prospects." Educational Theory 41.3 (1991): 311-320.

Beck, C. "Postmodernism, Pedagogy, and Philosophy of Education: PES Presidential Address." Philosophy of Education 1993 (PES Proceedings): 1-13. Urbana, IL: Philosophy of Education Society, 1993 a.

Beck, C. Learning to Live the Good Life: Values in Adulthood. Toronto: OISE Press, 1993b.

Beck, C. and Kosnik, C. "The Importance of the University Campus Program in Pre-service Teacher Education: A Canadian Case Study.” Journal of Teacher Education 53.5 (2002a): 420-432.

Beck, C. and Kosnik, C. "Components of a Good Practicum Placement: Student Teacher Perceptions." Teacher Education Quarterly 29.2 (2002b): 81-98.

Beck, C. and Kosnik, C. Innovations in Teacher Education: A Social Constructivist Approach. Albany, NY: State University New York Press, 2006.

Brubacher, J. Modern Philosophies of Education. New York: McGraw-Hill, 1939.

Carr, W. For Education: Towards Critical Educational Inquiry. Buckingham: Open University Press, 1995.

Dewey, J. Democracy and Education. New York: Macmillan, 1916.

Kosnik, C. and Beck, C. "The Action Research Process as a Means of Helping Student Teachers Understand and Fulfill the Complex Role of the Teacher." Educational Action Research 8.1 (2002): 115-136.

Kosnik, C. and Beck, C. Priorities in Teacher Education: The 7 Key Elements of Pre-service Preparation. London: Routledge, 2009.

O'Connor, D. J. An Introduction to the Philosophy of Education. London: Routledge \& Kegan Paul, 1957.

Scheffler, I. The Anatomy of Inquiry. London: Routledge \& Kegan Paul, 1964.

Soltis, J., ed. Philosophy and Education, 80th NSSE Yearbook, Part I. Chicago: National Society for the Study of Education. 1981.

\section{Works That Have Significantly Influenced My Thinking}

Aristotle. Nicomachean Ethics. Trans. J.A.K. Thomson. London: Penguin, 1953.

Ainscow, M., T. Booth, and A. Dyson. Improving Schools, Developing Inclusion. London: Routledge, 2006.

Derrida, J. Margins of Philosophy. Trans. Alan Bass. Chicago: University of Chicago Press, 1972/1982.

Dewey, J. Experience and Education. New York: Collier-Macmillan, 1938.

Foucault, M. Michel Foucault: Aesthetics, Method, and Epistemology. Ed. J.D. Faubion. New York: The New Press, 1998.

Freire, P. Pedagogy of the Oppressed. New York: Herder \& Herder, 1968/1972.

Lankshear, C., and M. Knobel (2003). New Literacies: Changing Knowledge and Classroom Learning. Buckingham: UK: Open University Press, 2003.

Lortie, D. Schoolteacher: A Sociological Study. Chicago: University of Chicago Press, 1975.

Martin, J.R. The Schoolhome. Cambridge, MA: Harvard University Press, 1992.

Meier, D. The Power of Their Ideas. Boston: Beacon Press, 1995.

Noddings, N. The Challenge to Care in Schools: An Alternative Approach (2nd edition). New York: Teachers College Press, 2005.

Rorty, R. Contingency, Irony, and Solidarity. Cambridge, UK: Cambridge University Press, 1989.

Schon, D. The Reflective Practitioner. New York: Basic Books, 1983.

Zeichner, K. "Beyond the Divide of Teacher Research and Academic Research." Teachers and Teaching: Theory and Practice 1.2 (1995): 153-172. 